\title{
Magnetic Nanoparticle Immobilized Cellulase Enzyme for Saccharification of Paddy Straw
}

\author{
Ajay Kumar, Surender Singh* and Lata Nain \\ Division of Microbiology, ICAR-Indian Agricultural Research Institute, \\ New Delhi-110 012, India \\ *Corresponding author
}

\begin{abstract}
A B S T R A C T
The production of the bioethanol from the vast quantity of ligno-cellulosic (LC) biomass using cellulases and yeasts has been suggested as an alternate energy source and offers potential to reduce the burden on fast depleting fossil fuel reservoirs. The major bottlenecks in commercial production of second generation bioethanol are complex feed stocks, high cost of enzymes and non-availability of co-fermenting yeasts. Immobilization of commercial enzyme (Cellic CTec3) on five nanoparticle (Iron oxide, Silicon oxide, Magnesium oxide, Zinc oxide and Silver oxide) were studied by two different methodsphysical adsorption and covalent coupling. For covalent coupling method, nanoparticles were activated with aminopropyltriethoxysilane (APTES). The enzyme-nanoparticle formulations were screened in the terms of protein binding and immobilization efficiency. Iron oxide-enzyme formulations were found to perform best with 60 to $80 \%$ immobilization efficiency. Besides better thermo-tolerance, the covalently immobilized enzyme showed better catalytic efficiency. The saccharification yields of the free and immobilized enzyme under optimized condition $\left(60{ }^{\circ} \mathrm{C}\right.$ temperature, $5.0 \mathrm{pH}$ and $6 \%$ substrate loading) were compared. The commercial immobilized enzyme showed slightly lower sugar yield ( $314.77 \mathrm{mg} / \mathrm{gds})$ as compared to the free enzyme $(366.6 \mathrm{mg} / \mathrm{gds})$ with 45 $\%$ enzyme activity recovery. Bioethanol production from the lignocellulosic biomass can be made economical feasible by using the covalently immobilized magnetic enzyme nanoparticle complex. Besides bioethanol, the prepared enzyme formulation can be used in textile, detergents and food industries.
\end{abstract}

\section{Introduction}

World's increasing interest toward nonpetroleum energy sources especially lignocellulosic ethanol has revitalized the research on renewable energy sources. The major driving forces behind the renewed interests in biofuels are increased demand of energy for transportation and industries, fast depleting fossil fuels reservoirs and environmental concerns like global climate change. Therefore, it is important for both developing and developed countries to work towards sustainable fuels for energy security. Biofuels derived from food crops like corn, sugarcane, sugar beet ( $1^{\text {st }}$ generation biofuel $)$ have potential but they compete with food production because of limited land 
availability. Lignocellulosic bioethanol $\left(2^{\text {nd }}\right.$ generation biofuel) does not compete with food production because it uses the agriculture waste materials, urban organic waste material and that's why it is environmentally more sustainable (Naik et al., 2010). Hence, bioethanol developed from the cheaper and more abundant lignocellulosic biomass is seen as the most feasible option especially as transport fuels for reducing petroleum consumption and as chemical feedstock for other industries.

India being one of the fastest growing economies of world would require additional energy sources to meet the demands of industries and transport sector. The national policy on biofuel approved by the Government of India (GOI) in 2009 encourages the use of renewable energy sources as alternate fuel for mixing in the transport fuels. This policy has planned of $20 \%$ biofuel blending (bio-diesel and bio-ethanol) by 2017. Currently, India is producing bioethanol from the sugar industry by product molasses which is neither economical nor sustainable. Due to the insufficient supply of the sugar molasses the government of India is not able to fulfill the compulsory blending of 5 percent ethanol in petrol (gasoline). Therefore, ethanol from lignocellulosic biomass is seen as an important viable option to meet the future energy demands (Sukumaran et al., 2010). Lignocellulosic (LC) biomass contains glucose polymer cellulose $(40-50 \%)$, a sugar heteropolymer hemicellulose (25-35\%) and a non-fermentable monolingual polymer lignin (15-20\%) (Holtzapple 1993).The lignocellulosic biomass composition varies from plant to plant and age of plant. The hydrolysis product of cellulosic polymers, glucose, can be readily fermented into ethanol or other high value added biochemicals. Success of LC bioethanol is dependent on the development of economically sustainable technologies by employing recent technologies and cheaper starting materials like agro-residues. However, the current bioethanol production process involves 3 major steps (pre-treatment, saccharification and fermentation) and is not competitive with crude at present. The major bottlenecks in commercial exploitation of LC bioethanol are recalcitrant nature of raw material, high cost of enzymes for saccharification and nonavailability of co-fermenting yeasts. Many novel methods including physico-chemical and biological have been used successfully for removing lignin and improving the saccharification efficiency of various feedstocks (Alvira et al., 2010; Saritha et al., 2011). Cellulase that hydrolyses $\beta-1,4$ glycosidic bonds of the crystalline complex of cellulosic crystals to produce glucose, is complex mixture of endoglucanase, exoglucanase and $\beta$ glucosidase. The multicomponent cellulase enzymes is rapidly inactivated during saccharification due to denaturation and unspecific binding with lignin (Chundawat et al., 2017). There are reports on the stabilization of cellulase enzymes by modulation of medium components, chemical crosslinking, protein engineering or enzyme immobilization (Khoshnevisan et al., 2011). Many useful commercial cellulase cocktails namely Accelerase, Cellulocast, Cellic CTec 2\&3, Novozyme 88 are available in market but their cost is still very high for an economically feasible process. Moreover, these enzymes are sensitive to end product inhibition. Immobilizing the enzyme on/in a solid matrix support can avoid deactivation of enzyme. Immobilization of the cellulase enzyme on different nano-materials like magnetic supports has been reported and is known to enhance temperature tolerance and activity besides creating an opportunity for recycling for future use (Jordan et al., 2011). Enzymes can be immobilized with nanoparticles by many different ways like physical adsorption, entrapment and covalent binding (Chen and 
Duan 2015). The cellulase immobilization has advantages of more hydrolytic activity and reusability of the enzyme. However, complete recovery of the bound enzyme from the nanoparticle is the main obstacle with the reusability. The immobilization also alters the temperature and $\mathrm{pH}$ optima of the enzyme and may be useful in processes like simultaneous saccharification and fermentation (SSF) which requires similar operating conditions for cellulases and yeasts.

Immobilization using various nanoparticles can be employed as a viable solution to conserve the enzyme activity under these unfavourable conditions. Immobilized enzymes have been used for developing sensors and in food industries but there is paucity of information on nanoparticle assisted saccharification for bioethanol production from lignocellulosic biomass.

Therefore, the main focus of research work is to immobilize the cellulase onto different nanoparticle to achieve better saccharification and to explore the enzyme reusability options. Further, enzymes are most expensive reagents in saccharification and are potentially recyclable but collecting the free enzyme from the treated bath is difficult. However, the iron oxide nanoparticles allows for the magnetic separation of the immobilized cellulase.

\section{Materials and Methods}

\section{Enzyme and materials}

Commercial enzyme (Cellic $®$ CTec3) from Novozyme was used. Nanoparticles viz. Silicon dioxide $\left(\mathrm{SiO}_{2}\right.$, $\mathrm{Zinc}$ oxide $(\mathrm{ZnO})$, Silver oxide $\left(\mathrm{Ag}_{2} \mathrm{O}\right)$, Magnesium oxide $(\mathrm{MgO})$, Iron oxide $\left(\mathrm{Fe}_{2} \mathrm{O}_{3}\right)$ and chemicals like 3aminopropyltriethoxysilane (APTES) glutaraldehyde and were purchased from Sigma Aldrich (USA). The Bradford reagent was purchased from G-Bioscience (USA).

\section{Enzyme assays}

Cellulolytic activities (CMCase, FPase, xylanases \& $\beta$-glucosidase) were determined in original enzyme, bound enzyme and unbound fraction.

\section{FPase (EC 3.2.1.91) activity}

FPase activity or exo- $\beta$-glucanase activity of the enzyme was determined using the Whatman No.1 filter paper $(50 \mathrm{mg})$ as a substrate by incubating in $0.5 \mathrm{ml}$ citrate buffer $\left(\mathrm{pH} 4.8\right.$ ) and $0.5 \mathrm{ml}$ enzyme sample at $50^{\circ} \mathrm{C}$ for $1 \mathrm{~h}$ (Ghose 1987). After incubation, released sugars were measured by DNSA method (Miller 1959). One enzyme unit was expressed as release of the $\mu$ mole of reducing sugar per minute during hydrolysis. One substrate blank and one enzyme blank run simultaneously to measure the sugar which was already present in the substrate and enzyme. In enzyme blank, $0.5 \mathrm{ml}$ enzyme and $0.5 \mathrm{ml}$ citrate buffer $(0.05 \mathrm{M})$ was added. In substrate blank $50 \mathrm{mg}$ filter paper and $1 \mathrm{ml}$ citrate buffer was added.

\section{CMCase (EC 3.2.1.4) activity}

CMCase activity of the enzymes was determined by adding in tube $0.5 \mathrm{ml} \mathrm{CMC}$ substrate $(2 \%)$ and $0.5 \mathrm{ml}$ enzyme and kept for the incubation at $50^{\circ} \mathrm{C}$ for $30 \mathrm{~min}$. in water bath (Ghose 1987). Post incubation, tubes were kept at room temperature and reducing sugars were determined by using DNSA method as described above.

\section{pNPGase ( $\beta$-D-glucosidase; EC 3.2.1.21) activity}

The $\beta$-glucosidase activity of enzyme was determined by incubating $0.5 \mathrm{ml}$ enzyme and $0.5 \mathrm{ml}$ of substrate ( $\mathrm{p}$-nitrophenyl $\beta$-Dglucopyranoside) at $50^{\circ} \mathrm{C}($ Wood and Bhat 1988). Following incubation, the reaction was 
stopped using Glycine buffer of $\mathrm{pH} 10.8$ (1 $\mathrm{ml}$ ) and the concentration was checked at 430 $\mathrm{nm}$. The activity was expressed in terms of release of $\mu$ moles of $\mathrm{p}$-nitrophenol produced per $\mathrm{ml}$ of enzyme per minute.

\section{Xylanases activity}

Xylanases activity of the enzyme was checked by mixing of enzyme and xylan $(0.5 \mathrm{ml}$ of $1 \%$ solution) followed by the incubation at $50^{\circ} \mathrm{C}$ for $30 \mathrm{~min}$ (Ghose and Bisaria, 1987). Reducing sugars were quantified by DNSA method. One enzyme unit was expressed in terms of $\mu$ mole of product (xylose) formed per min under standard assay conditions.

\section{Protein assay}

Protein concentration in the culture filtrate was checked using Bradford method (1976). Enzyme $(100 \mu \mathrm{l})$ was mixed with $1 \mathrm{ml}$ of Bradford reagent (G-Biosciences) and mixture was vortexed and incubated for 10 minutes at room temperature for blue colour development. The concentration of protein was determined by spectrophotometry at 595 $\mathrm{nm}$ and standard curve of the different concentrations $(1-100 \mu \mathrm{g} / \mathrm{ml})$ of bovine serum albumin (BSA).

\section{Immobilization of enzyme}

\section{Physical adsorption}

Immobilization of the commercial enzyme on the different nanoparticles by physical adsorption were performed by mixing $50 \mathrm{mg}$ different nanoparticle which were prepared in sodium citrate buffer and $3 \mathrm{ml}$ of enzyme ( 2 $\mathrm{mg} / \mathrm{ml}$ ) solution (prepared in sodium citrate buffer, $\mathrm{pH} 4.8$ ). The mixture was incubated at $25^{\circ} \mathrm{C}$ with continuous shaking on revolving shaker for $4 \mathrm{~h}$. Postincubation, the centrifugation of the samples were done at $10000 \mathrm{rpm}$ for $5 \mathrm{~min}$ at $4^{\circ} \mathrm{C}$. Immobilized nanoparticles were washed with sodium citrate buffer to remove the loosely bound enzyme molecules. Total protein and enzyme activities were checked in both unbound and bound fraction to measure the immobilization efficiency and residual activities (Khoshnevisan et al., 2011).

Covalent coupling of enzymes and nanoparticles

\section{Preparation of ligand-nanoparticles}

Initially the nanoparticles were modified by mixing $0.1 \mathrm{~g}$ nanoparticles in $12 \mathrm{ml}$ ethanol and $0.5 \mathrm{ml}$ deionized water. After that, $1 \mathrm{ml}$ ammonium hydroxide (30\%) and $0.25 \mathrm{ml}$ of 3aminopropyltriethoxysilane (APTES) were mixed in the sample. The solution was stirred continuously for $24 \mathrm{~h}$ at room temperature followed by centrifugation and washing with ethanol. The modified nanoparticles were treated with $2 \mathrm{ml}$ of $25 \%$ glutaraldehyde and 3 $\mathrm{ml}$ deionized water. The solution was stirred again continuously for $24 \mathrm{~h}$ at room temperature. Finally the modified nanoparticles were separated and washed thrice with $0.05 \mathrm{M}$ sodium citrate buffer $(\mathrm{pH}$ 4.8) to remove the loosely bound reagents (Alahakoon et al., 2012).

\section{Immobilization of enzyme}

Immobilization of cellulase (Cellic CTec3) on the modified nanoparticles was performed by mixing the $10 \mathrm{ml}(1 \mathrm{mg} / \mathrm{ml})$ of enzyme and 0.1 $\mathrm{mg}$ functionalized nanoparticles. The mixture was incubated for $18 \mathrm{~h}$ at room temperature. Following incubation, the centrifugation of the mixture was done to recover the ENC followed by washing thrice with sodium citrate buffer ( $\mathrm{pH}$ 4.8) to remove loosely bound proteins molecules. Protein content and enzyme activities of both bound and unbound fraction was determined using standard assays as described earlier. 


\section{Determination of immobilization efficiency of nanoparticles}

Immobilization efficiency for different nanoparticles was measured by measuring the enzyme activities and protein in the initial solution of enzyme, supernatant and washing (Alahakoon et al., 2012).

Immobilization efficiency $=\frac{\mathrm{Mi}-\mathrm{Ms}}{\mathrm{Mi}} \times 100$

Mi. = Initialenzyme activity/protein concentration

$\mathrm{M}_{\mathrm{S}}=$ Enzyme activity/Protein concentration in supernatant and washing.

Determination of optimum incubation time and protein loading for preparation of magnetic enzyme nanoparticle complex (MENC)

The optimum incubation time and protein loadingwere measured by incubating the functionalized nanoparticles with varying amount of protein for different time intervals. Post incubation, protein loading ( $\mu \mathrm{g} / \mathrm{mg} \mathrm{NP}$ ) was checked using Bradford protein assay.

Determination of optimum temperature, pH optima and kinetic parameters for free and immobilized enzymes

The optimum temperature for both free and immobilized commercial enzyme were determined using the range of temperature $\left(40-80^{\circ} \mathrm{C}\right)$. The substrate were prepared in buffer of different $\mathrm{pH}(3,4,5,6$ and 7$)$ to determine the optimum $\mathrm{pH}$ of the free and immobilized enzyme and enzyme activity was determined using standard assay as described earlier. Kinetic parameters such as $\mathrm{V}_{\max }, \mathrm{K}_{\mathrm{m}}$ and kinetic efficiency $\left(\mathrm{V}_{\max } / \mathrm{K}_{\mathrm{m}}\right)$ were measured under steady state conditions using various concentration of CMC as substrate.

\section{Alkali pretreatment of the paddy substrate}

Paddy straw was pretreated using $1 \% \mathrm{NaOH}$ with $10 \%$ substrate loading in Erlenmeyer flask and the flask was kept static for $1 \mathrm{~h}$ followed by 6-7 washing with distilled water in equal ratio until the $\mathrm{pH}$ of washed water reaches near neutral. Finally biomass was dried and stored in refrigerator at $4^{\circ} \mathrm{C}$ as such till used.

\section{Optimization of saccharification parameters}

The optimization of the saccharification parameters of the best ENC like temperature, $\mathrm{pH}$ and substrate loading was done by using one factor at a time approach. The saccharification of the alkali pretreated paddy straw was performed using different temperature $\left(30^{\circ} \mathrm{C}-60^{\circ} \mathrm{C}\right), \mathrm{pH}$ range $(4.0-6.0)$ and at different substrate loading $(1,2,4,5 \%)$. The reducing sugars released were determined using HPLC (discussed in next sections).

\section{Saccharification of alkali pretreated paddy straw under optimized conditions}

Saccharification of alkali pre-treated paddy straw was done as per NREL LAP-009 method (Brown and Torget, 1996) using free enzyme and best enzyme nanoparticle complex (ENC).

Pretreated substrate $(0.6 \mathrm{~g})$ and free or immobilized enzyme (20 FPU/g substrate) were mixed in screw capped bottles $(50 \mathrm{ml})$ and final volume was made up to $10 \mathrm{ml}$ by adding $0.05 \mathrm{M}$ citrate buffer ( $\mathrm{pH} 4.8$ ).

Then incubation of the bottles were carried out in shaking water bath at $50^{\circ} \mathrm{C}$ for $72 \mathrm{~h}$. Aliquots were taken out at different intervals of time from the bottles and the amount of reducing sugars released was determined by HPLC. 
HPLC analysis for quantification of reducing sugars released

The reducing sugars released during saccharification process were determined using the high performance liquid chromatography (HPLC). The HPLC system consisted of auto sampler, refractive index detector (RID), Waters 515 binary pump, column oven and pump control module. The mobile phase was $5 \mathrm{mM} \mathrm{H}_{2} \mathrm{SO}_{4}$ with flow rate of $0.5 \mathrm{ml} / \mathrm{min}$. The column Biorad's Aminex $\mathrm{HPX}-87 \mathrm{H}$ ) was operated at $50^{\circ} \mathrm{C}$ temperature.

Recovery of ENC and calculation of residual activities

After the completion of the saccharification process the ENC were recovered by the centrifugation of the sample and these ENC were washed with citrate buffer. The residual activities were determined using the method described earlier for FPase. The recovered enzyme was used again for saccharification of alkali treated paddy straw. The data was analyzed statistically by using completely randomized design (CRD) as outlined in Panse and Sukhatme (1954) and the test of significance was done at the $5 \%$ level.

\section{Results and Discussion}

Screening of nanoparticles for their immobilization efficiency

In this study five different nanoparticles Iron oxide $\left(\mathrm{Fe}_{2} \mathrm{O}_{3}\right)$, Silicon dioxide $\left(\mathrm{SiO}_{2}\right)$, Zinc oxide $(\mathrm{ZnO})$, Silver oxide $\left(\mathrm{Ag}_{2} \mathrm{O}\right)$ and Magnesium oxide $(\mathrm{MgO})$ were used for the immobilization of the enzyme and the best combination was selected on the basis of protein loading and immobilization efficiency.

The immobilization efficiency of all the ENPs prepared via physical adsorption and covalent coupling are shown in Figure 1. The result clearly showed that magnetic enzyme nanoparticle (ENPs) retained highest enzyme activities among all the nanoparticles in both physically adsorption and covalent coupling methods. Although the $\mathrm{SiO}_{2}$ showed higher protein binding than MNPs but the immobilization efficiency in the terms of enzyme activities were poorer. $\mathrm{ZnO}$ showed the least immobilization efficiency among all the nanoparticles. The immobilization efficiency of Iron oxide was found to be 50 to $60 \%$ for physically adsorbed enzyme but covalently bound enzyme showed 60 to $80 \%$ immobilization efficiency.

In physical adsorption method, again magnetic nanoparticle-enzyme complex showed the highest immobilization efficiency in terms of enzyme activities and protein binding. The highest immobilization efficiency of 59.58\% was shown by the enzyme FPase followed by CMCase (59.23\%) and xylanase (59.12\%).

In covalent coupling method also, MENP was found best in the terms of immobilization efficiency and protein binding. Among different enzymes, highest immobilization efficiency was shown by pNPGase.

Many scientists have shown that when enzymes immobilized on the solid support, immobilization efficiency ranges from 50145\% (Cheng and Chang, 2013; Samra et al., 2012; Khoshnevisan et al., 2011). Physical adsorption method of the immobilization is very simple and does not require any ligand chemical which makes this method cost effective. This method involves direct attachment between enzyme and nanoparticles with the help of the hydrogen bonding, hydrophobic interaction and van der Waals forces. Physical adsorption is reversible in nature by which NPs support can be recovered easily after the inactivation of the enzyme and can be reused or the immobilization. However, there are many drawbacks in the physical 
adsorption method. Lower immobilization efficiency as reported in present study is the one of the commonly reported drawbacks of the physical adsorption. The leaching of the enzyme is also one of problems in physical adsorption method due to which the efficacy of this method reduce during the repeated uses (Liao et al., 2010). Ahmad and Sardar (2015) have reported the lower enzyme activities of the silicon oxide in spite of the better protein binding than the magnetic nanoparticles which might be due to the blocking of the active sites of the enzyme by nanoparticles.

Magnetic nanoparticles have been the most studied and reported by the scientist because of their large surface area, environment compatibility, lower cost, high protein binding and ease of recovery from reaction mixtures (Netto et al., 2013). The covalent coupling methods of the immobilization are more stable than physical adsorption due the strong crosslinking of the enzyme and nanoparticles by using the ligand. The covalently bound enzyme nanoparticle complex can be used repeatedly without any leaching of enzyme.

The immobilization of the enzyme on the nanoparticle was confirmed by the Fourier transform infrared spectroscopy (FTIR) analysis (data not shown). The FTIR spectra clearly showed that the binding of the enzyme on the nanoparticle is confirmed by the band at $2100 \mathrm{~cm}^{-1}$. The confirmation of binding of enzyme on nanoparticle has been reported by many scientists using the Fourier transform infrared spectroscopy (FTIR) (Cheng and Chang, 2013; Khoshnevisan et al., 2011).

\section{Determination of optimum incubation time and protein loading for preparation of MENC}

The efficient and cost effective ENP complex should show high protein loading in shortest incubation time. The protein loading of
$63.6 \mu \mathrm{g}$ protein/mg NPs was achieved within short incubation period of $15 \mathrm{~h}$. Further, the optimization of the incubation time was carried out by incubating for different time. The maximum protein binding was found after $15 \mathrm{~h}$ of incubation of the enzyme and functionalized nanoparticles (Figure 2). Only few studies have reported the optimization of protein loading and incubation time. Khoshnevisan et al., (2011) reported cellulase loading to magnetic NP ratio of 0.033 which was very low. However, some other researchers like Cheng and Chang (2013) and Samra et al., (2012) have reported a higher protein loading of $130 \mathrm{mg} / \mathrm{g}$ magnetic NP and $117 \mathrm{mg} / \mathrm{g}$ silica NP for mannosidase and cellulase respectively. The enzyme loading on the nanoparticles depend upon the different factors like properties of enzyme, size and shape of NPs and ligand properties (Mohamad et al., 2015).

Determination of temperature and $\mathbf{p H}$ optima and kinetic parameters for free and immobilized enzyme

The enzyme activity of the free and immobilized enzyme was measured in the range of temperature from 40 to $80^{\circ} \mathrm{C}$ by using $\mathrm{CMC}$ as a substrate. The relative activity of free and immobilized enzyme on magnetic NPs is depicted in Figure 3.

The result clearly indicated that the optimum temperature for the free and immobilized enzyme was $50^{\circ} \mathrm{C}$ and $60^{\circ} \mathrm{C}$ respectively. This report shows that the immobilization of the enzyme on the solid support increased the thermostability of the enzyme which can tolerate higher temperature whereas the free enzyme denature at this temperature. The similar result has been reported where immobilized cellulase enzyme was more stable than the free cellulase enzyme at the temperature higher than $60^{\circ} \mathrm{C}$ (Chen and Duan, 2015). 
Fig.1 Immobilization efficiency (\%) of nanoparticles by physical adsorption (A) and covalent coupling (B)

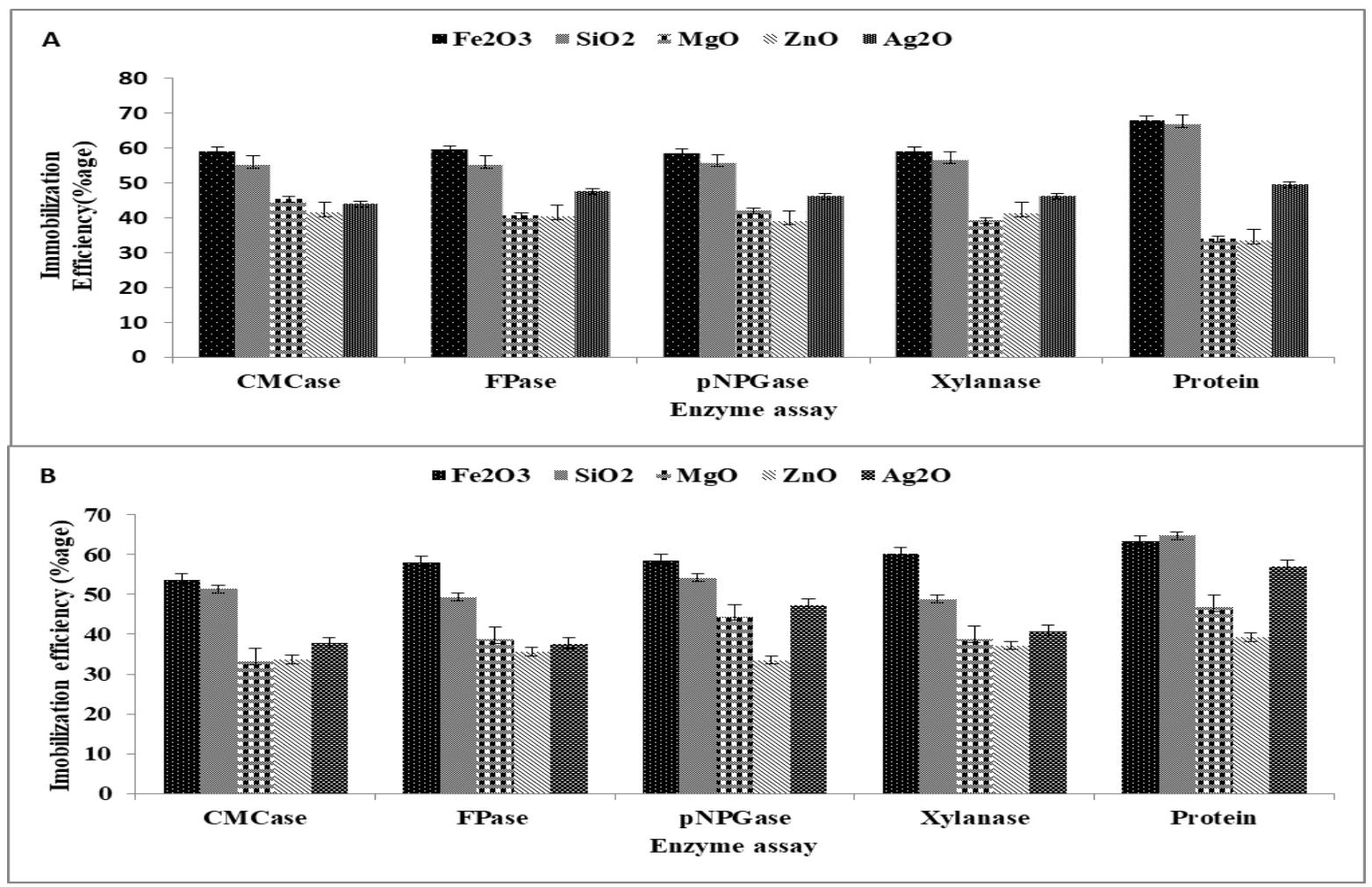

Fig.2 Optimization of protein loading (A) and incubation time (B) for preparing covalently bound MNC for commercial enzyme

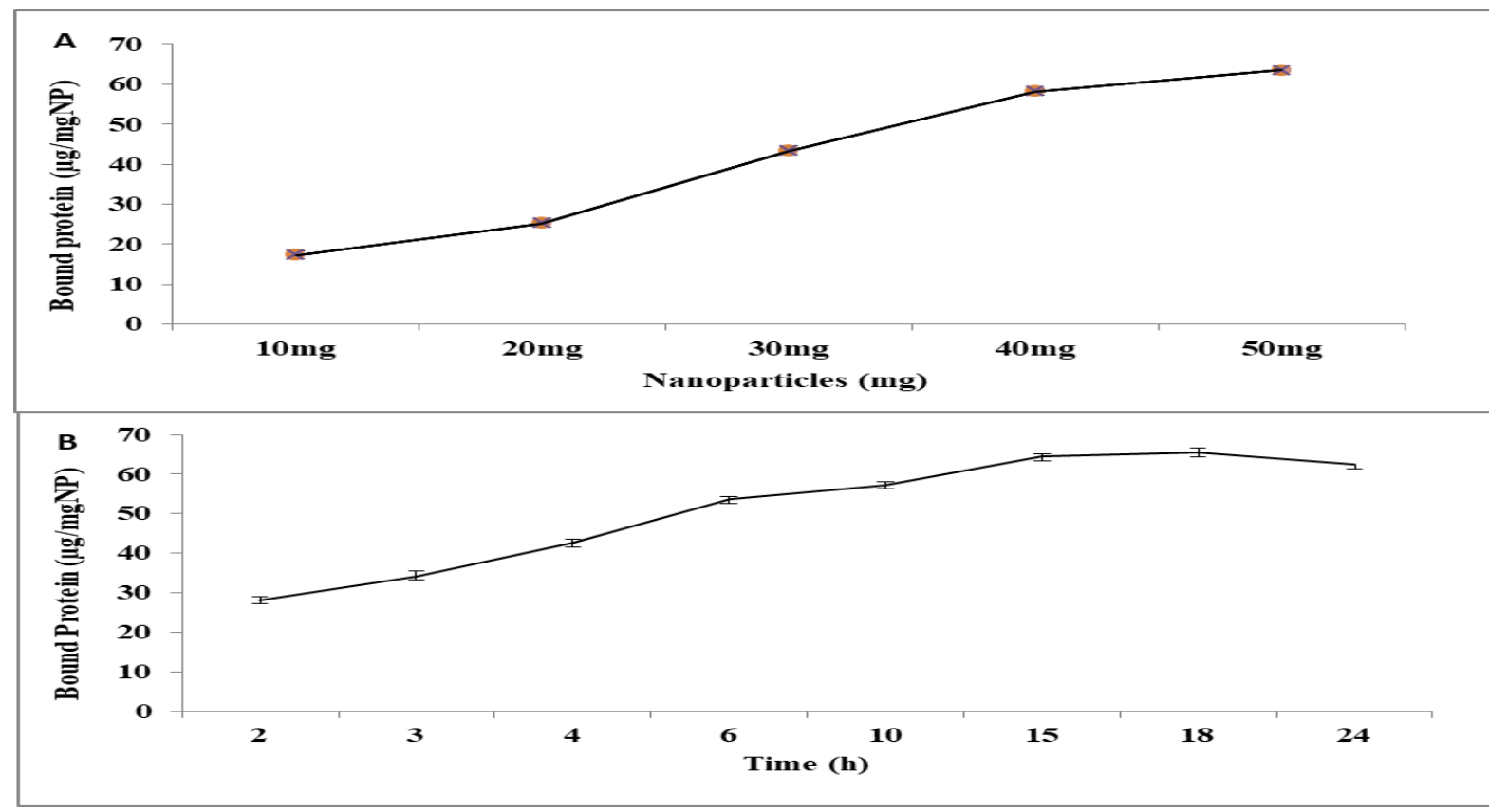


Fig.3 The comparisons of free and immobilized commercial cellulase for optimum temperature $(\mathrm{A})$ and $\mathrm{pH}(\mathrm{B})$

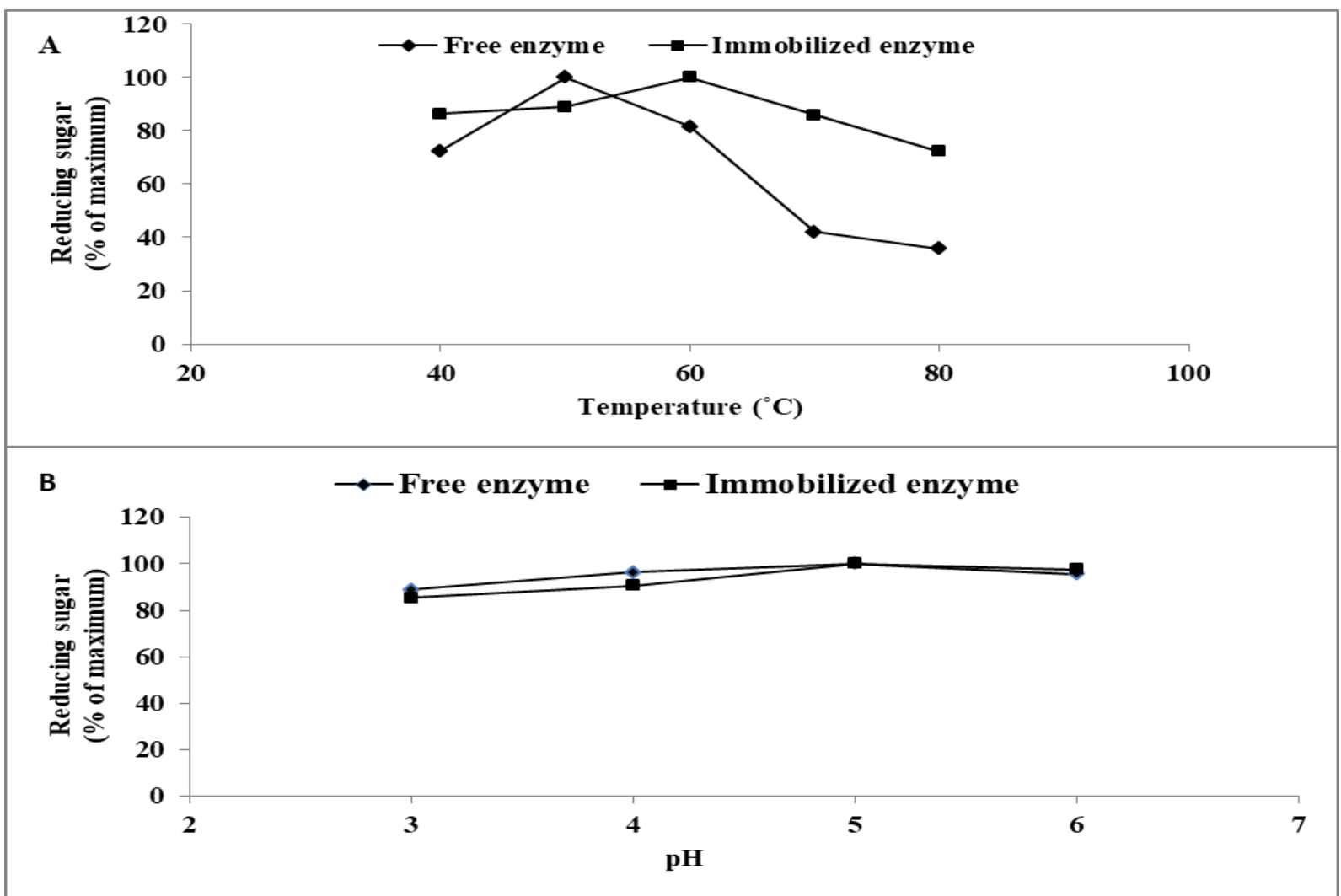

Fig.4 Comparisons of the saccharification yield of the free and immobilized commercial enzyme at different time interval

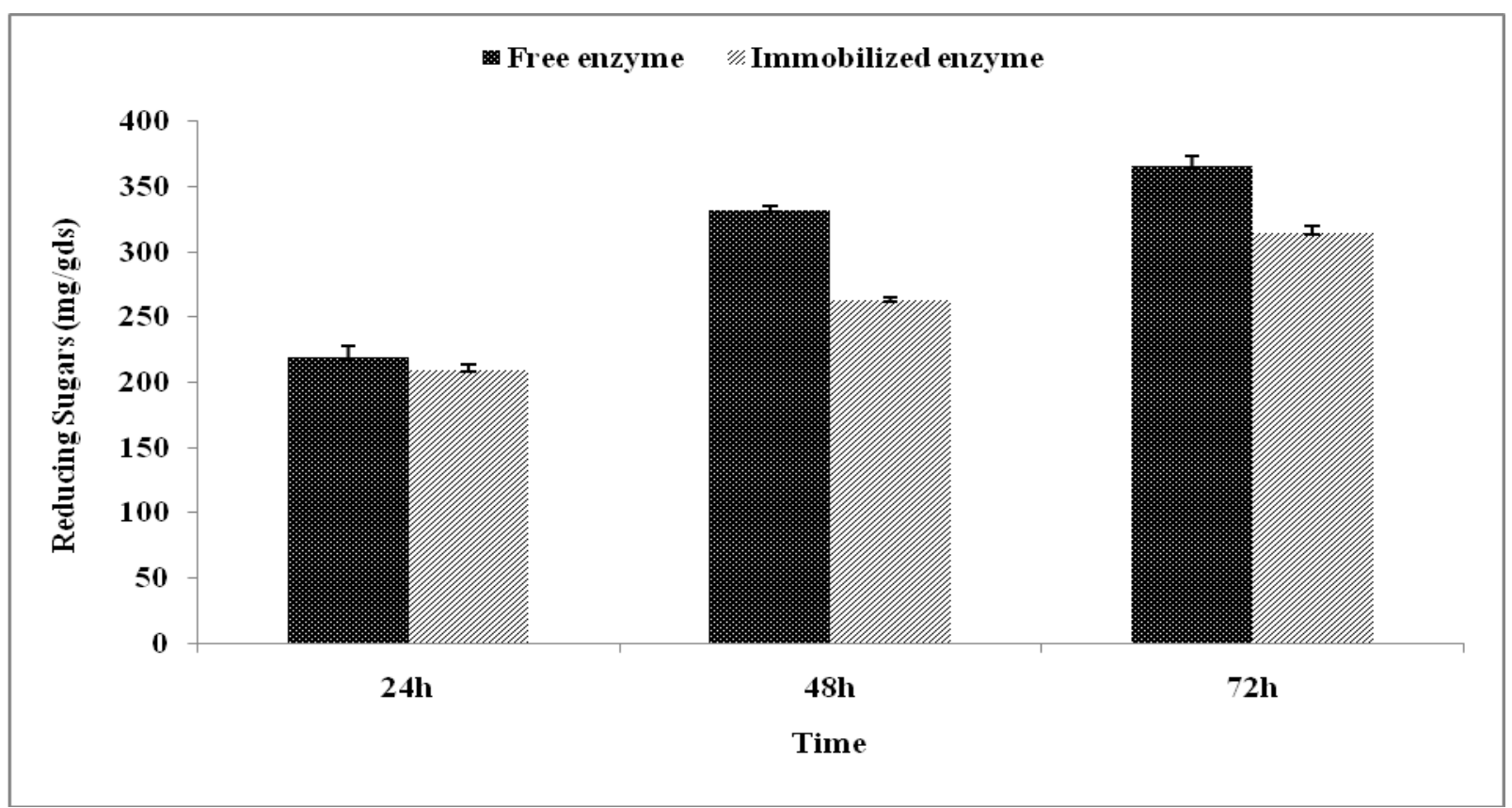


Many other reports are also available which showed that immobilized enzyme has more thermostability as compared to the free enzyme (Huang et al., 2015; Jordan et al., 2011). The reason for higher thermostability of the immobilized enzyme as compared to the free enzyme may be the less flexibility of the enzyme on the solid support that increased the tolerance against denaturation and unfolding of the enzyme due to the conformational changes. The increase in the thermostability of the immobilized enzyme is directly related to the covalent bonding of the enzyme and solid support (Jaroslava, 1978).

The optimum $\mathrm{pH}$ for the immobilized enzyme was same as free enzyme but immobilized enzyme showed more stability over the broader $\mathrm{pH}$ range as compared to the free enzyme (Figure 3). The reason for stability over broad range may be the interactions between charge on the carrier molecule and charged group present on the enzyme molecules which were used for the covalent coupling of the immobilization. It is documented that the optimum $\mathrm{pH}$ for the immobilized and free enzyme showed no difference but the immobilized enzyme showed the broader $\mathrm{pH}$ stability as compared to the free enzyme (Abraham et al., 2014; Tao et al., 2016).

\section{Kinetic parameters}

The kinetic parameters of both the free and immobilized cellulase enzyme were measured using different concentrations of CMC. The result indicated that the immobilized enzyme has higher $\mathrm{K}_{\mathrm{cat}}$ value (4.73) and lower $\mathrm{K}_{\mathrm{m}}$ $(20.11 \mathrm{~g} / \mathrm{l})$ value as compared to the free enzyme. The similar result has been reported that $\mathrm{K}_{\mathrm{m}}$ value of the free and immobilized enzyme were 2.6 and 0.87 respectively (Abraham et al., 2014). The decrease in the $\mathrm{K}_{\mathrm{m}}$ value and increase in the $\mathrm{K}_{\mathrm{cat}}$ value makes the rate of reaction faster. The catalytic efficiency can be assessed by the kinetic parameters $\left(\mathrm{K}_{\mathrm{m}}, \mathrm{V}_{\max }\right.$ and $\left.\mathrm{V}_{\max / \mathrm{Km}}\right)$. The affinity of the enzyme for the substrate changes with the changes in kinetic parameters. The reason for the variation in the kinetic parameters might be due to the several factors like protein conformational changes induced by the steric hindrance, attachment to the support, and diffusional effects.

\section{Enzymatic saccharification of alkali-pre- treated paddy straw using MENC}

Saccharification of alkali pre-treated paddy straw with commercial immobilized enzyme under optimized conditions $\left(\mathrm{pH} 5.0,60{ }^{\circ} \mathrm{C}\right.$ temperature, and $6 \%$ substrate loading) resulted in release of more reducing sugars (366.43mg/gds) than immobilized enzyme (314.77 mg/gds) reducing sugars (Figure 4). Kumar et al., (2017) used MENP prepared from indigenous enzyme from Aspergillus niger SH3 for saccharification of alkali pretreated paddy straw and observed that immobilized enzyme released $11 \%$ more sugar than free enzyme. However, the reverse trend observed in present study might be due to blocking of active enzyme site by the sugars present in enzymes formulation used for preparing ENPC. Various sugars are added to preserve the activity of enzymes during storage (Gonçalves et al., 2013).

\section{Recovery of ENC and calculation of residual activities}

After the saccharification of the paddy straw, ENP complex were recovered and enzyme activity (FPase) was measured to determine the residual activity. It was found that 70 and $45 \%$ enzyme activity is left after the first and second saccharification cycle respectively. The recovery and reuse of the immobilized enzyme may help to reduce the overall cost of process during bioethanol production. Magnetic nanoparticles are most studied and 
used for the immobilization of the enzyme because of the easy recovery by centrifugation or using magnates. However, such studies are more common for the high value enzymes used in diagnostic industries and pharmaceutical. Only few reports are available on the use of immobilized enzyme for saccharification of lignocellulosic biomass (Alftrén and Hobley, 2014).

The magnetic nanoparticle was found best among all the nanoparticles in terms of the immobilization efficiency. The magnetic ENC was used twice for the saccharification of the pre-treated paddy straw which can help to bring down the overall bioethanol production cost.

\section{Acknowledgment}

The authors are thankful to the Indian Council of Agricultural Research, New Delhi for providing fellowship towards the M.Sc. programme of the first author and National Fund for Basic, Strategic and Frontier Application Research in Agriculture (ICARNFBSFARA) for funding the research activities for biofuel project (NFBSFARA/AE2006/2010-11). We are also grateful to the Head, Division of Microbiology for providing necessary facilities for undertaking this study.

\section{References}

Abraham RE, Verma ML, Barrow CJ, Puri M (2014) Suitability of magnetic nanoparticle immobilised cellulases in enhancing enzymatic saccharification of pretreated hemp biomass. Biotechnology for Biofuels 7:90-90.

Ahmad R, Sardar M (2015) Enzyme Immobilization: An Overview on Nanoparticles as Immobilization Matrix. Biochemistry and Analytical Biochemistry 4 (2):1.
Alahakoon T, Koh JW, Chong XWC, Lim WTL (2012) Immobilization of cellulases on amine and aldehyde functionalized $\mathrm{Fe}_{2} \mathrm{O}_{3} \quad$ magnetic nanoparticles. Preparative Biochemistry and Biotechnology 42 (3):234-248.

Alftrén J, Hobley TJ (2014) Immobilization of cellulase mixtures on magnetic particles for hydrolysis of lignocellulose and ease of recycling. Biomass and Bioenergy 65:72-78.

Alvira P, Tomás-Pejó E, Ballesteros M, Negro MJ (2010) Pretreatment technologies for an efficient bioethanol production process based on enzymatic hydrolysis: A review. Bioresource Technology 101 (13):4851-4861.

Bradford MM (1976) A rapid and sensitive method for the quantitation of microgram quantities of protein utilizing the principle of protein-dye binding. Analytical biochemistry 72 (12): 248-254.

Brown L, Torget R (1996) Enzymatic saccharification of lignocellulosic biomass, chemical analysis and testing task laboratory analytical procedures (LAP 009). NREL Biomass Program.

Chen S-C, Duan K-J (2015) Production of Galactooligosaccharides Using $\beta$ Galactosidase Immobilized on Chitosan-Coated Magnetic Nanoparticles with Tris (hydroxymethyl) phosphine as an Optional Coupling Agent. International journal of molecular sciences 16 (6):12499-12512.

Cheng C, Chang KC (2013) Development of immobilized cellulase through functionalized gold nano-particles for glucose production by continuous hydrolysis of waste bamboo chopsticks. Enzyme and Microbial Technology 53 (6-7):444-451.

Ghose T, Bisaria VS (1987) Measurement of hemicellulase activities: part I 
Xylanases. Pure and Applied Chemistry 59 (12):1739-1751.

Ghose TK (1987) Measurement of cellulase activeties. Pure Appl Chem 59.

Gonçalves, H.B., Jorge, J.A., Oliveira, W.P., Souza, C.R.F., Guimarães, L.H.S. 2013. Extracellular $\beta$-fructofuranosidase from Fusarium graminearum: stability of the spray-dried enzyme in the presence of different carbohydrates. Journal of Microencapsulation, 30(7), 624-631.

Hagerman AE, Butler LG (1978) Protein precipitation method for the quantitative determination of tannins. Journal of Agricultural and Food Chemistry 26 (4):809-812.

Holtzapple M (1993) Cellulose. Encyclopedia of food science, food technology and nutrition 2:2731-2738.

Huang P-J, Chang K-L, Hsieh J-F, Chen S-T (2015) Catalysis of Rice Straw Hydrolysis by the Combination of Immobilized Cellulase from Aspergillus niger on $\quad \beta$-Cyclodextrin- $\mathrm{Fe}_{3} \mathrm{O}_{4}$ Nanoparticles and Ionic Liquid. BioMed research international 2015.

Jaroslava T (1978) Immobilized enzymes. In: Jaroslava $\mathrm{T}$ (ed) Journal of Chromatography Library, vol Volume 12. Elsevier, pp 365-386

Jordan J, Kumar C, Theegala C (2011) Preparation and characterization of cellulase-bound magnetite nano particles. Journal of Molecular Catalysis B-Enzymatic 68 (2):139-146.

Khoshnevisan K, Bordbar AK, Zare D, Davoodi D, Noruzi M, Barkhi M, Tabatabaei M (2011) Immobilization of cellulase enzyme on superparamagnetic nanoparticles and determination of its activity and stability. Chemical Engineering Journal 171 (2):669-673.

Kumar, A., Singh, S., Tiwari, R., Goel, R., \& Nain, L. (2017). Immobilization of indigenous holocellulase on iron oxide $\left(\begin{array}{ll}\mathrm{Fe}_{2} & \mathrm{O}_{3}\end{array}\right)$ nanoparticles enhanced hydrolysis of alkali pretreated paddy straw. International journal of biological macromolecules, 96, 538549.

Liao H, Chen D, Yuan L, Zheng M, Zhu Y, Liu X (2010) Immobilized cellulase by polyvinyl alcohol/ $/ \mathrm{Fe}_{2} \mathrm{O}_{3}$ magnetic nanoparticle to degrade microcrystalline cellulose. Carbohydrate Polymers 82 (3):600-604.

Miller G (1959) Use of dinitrosalicylic acid reagent for determination of reducing sugar. Anal Chem 31:426-428.

Mohamad NR, Marzuki NHC, Buang NA, Huyop F, Wahab RA (2015) An overview of technologies for immobilization of enzymes and surface analysis techniques for immobilized enzymes. Biotechnology \& Biotechnological Equipment 29 (2):205220.

Naik SN, Goud VV, Rout PK, Dalai AK (2010) Production of first and second generation biofuels: A comprehensive review. Renewable and Sustainable Energy Reviews 14 (2):578-597.

Netto CGCM, Toma HE, Andrade LH (2013) Superparamagnetic nanoparticles as versatile carriers and supporting materials for enzymes. Journal of Molecular Catalysis B: Enzymatic 8586:71-92.

Panse VG, Sukhatme PV (1954) Statistical methods for agricultural workers. ICAR, New Delhi (India)

Reese E, Mandels M (1963) Enzymatic hydrolysis of cellulose and its derivatives. Methods carbohydrate chem 3:139-142

Samra ZQ, Dar N, Athar MA (2012) Biocatalytic activity of recombinant human $\beta$-mannosidase immobilized onto magnetic nanoparticles for bioprocess. Preparative Biochemistry and Biotechnology 42 (1):97-112. 
Saritha M, Arora A, Lata (2011) Biological Pretreatment of Lignocellulosic Substrates for Enhanced Delignification and Enzymatic Digestibility. Indian Journal of Microbiology:1-9.

Sukumaran RK, Singhania RR, Mathew GM, Pandey A (2009) Cellulase production using biomass feed stock and its application in lignocellulose saccharification for bio-ethanol production. Renewable Energy 34 (2):421-424.

Sukumaran RK, Surender VJ, Sindhu R, Binod P, Janu KU, Sajna KV, Rajasree KP, Pandey A (2010) Lignocellulosic ethanol in India: Prospects, challenges and feedstock availability. Bioresource Technology 101 (13):4826-4833.
Tao Q-L, Li Y, Shi Y, Liu R-J, Zhang Y-W, Guo J (2016) Application of Molecular Imprinted Magnetic $\mathrm{Fe}_{3} \mathrm{O}_{4} @ \mathrm{SiO}_{2}$ Nanoparticles for Selective Immobilization of Cellulase. Journal of Nanoscience and Nanotechnology 16 (6):6055-6060.

Whitehead, T. A., Bandi, C. K., Berger, M., Park, J., \& Chundawat, S. P. (2017). Negatively supercharging cellulases render them lignin-resistant. ACS Sustainable Chemistry \& Engineering, 5(7), 6247-6252.

Wood TM, Bhat KM (1988) Methods for measuring cellulase activities. In: Willis A. Wood STK (ed) Methods in Enzymology, vol Volume 160. Academic Press, pp 87-112

\section{How to cite this article:}

Ajay Kumar, Surender Singh and Lata Nain. 2018. Magnetic Nanoparticle Immobilized Cellulase Enzyme for Saccharification of Paddy Straw. Int.J.Curr.Microbiol.App.Sci. 7(04): 881-893. doi: https://doi.org/10.20546/ijcmas.2018.704.095 